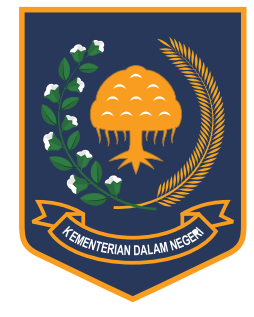

Jurnal Bina Praja 10 (1) (2018): 69-80

Jurnal Bina Praja

e-ISSN: 2503-3360 | p-ISSN: 2085-4323

Accreditation Number

735/AU2/P2MI-LIPI/04/2016

http://jurnal.kemendagri.go.id/index.php/jbp/index

\title{
THE INFLUENCE OF APPARATUS RESOURCE DEVELOPMENT ON THE EFFECTIVITY OF POPULATION ADMINiSTRATION SERVICE in Cianjur Regency, West Java
}

\author{
Hardiyansyah ${ }^{1,}{ }^{*}$, Ike Rachmawati ${ }^{2}$ \\ ${ }^{1}$ Universitas Bina Darma \\ Jl. Jenderal A. Yani No. 3 Palembang \\ South Sumatera, Indonesia \\ ${ }^{2}$ Universitas Muhammadiyah Sukabumi \\ Jl. R. Syamsudin No. 50 Sukabumi \\ West Java, Indonesia
}

Received: 6 March 2018; Accepted: 28 March 2018; Published online: 12 May 2018

DOI: $10.21787 / j b p .10 .2018 .69-80$

\begin{abstract}
This study is based on a phenomenon which indicates that population administration in terms of the registration process; family card (KK) and identity card (KTP) in Cianjur District has not been effective, because the service is still slow, the procedure is complicated, not timely, and not transparent. The purpose of this study is to the influence of human resources (apparatus) development dimension on the effectiveness of population administration services. This research uses quantitative design, with a descriptive quantitative method that explains and describes the level of human resources (apparatus) development towards the effectiveness of population administration service in Cianjur Regency. Respondents were selected by using Proportional Stratified Random Sampling technique. Primary data were collected through observation, questionnaires, and interviews; Respondents are apparatuses at the Department of Population and Civil Registry as well as apparatuses from 18 Sub-districts in Cianjur regency as many as 187 samples. Secondary data were obtained through study documentation. Data were analyzed by Structural Equation Model (SEM). The results show that the development of human resources (apparatus), including learning, education, development, and training dimension has positively affected the effectiveness of population administration services significantly. The research concluded that the influence of human resource development on the effectiveness of the population administration service in Cianjur Regency is determined by the dimensions of learning, education, development, and training. These influences imply that the four dimensions of human resource development (apparatus) have important roles in the effectiveness of population administration services in Cianjur Regency.
\end{abstract}

Keywords: Human Resources, Service Effectiveness, Population Administration

\section{INTRODUCTION}

Ideally, the implementation of public services by the government for the public in Indonesia well proceeds because substantively the local government has the authority and legal basis and technical guidance in the implementation of public services to the people in accordance with their respective duties and functions. However, in reality, it still shows different phenomena from what is supposed to be expected. The implementation of public services still cannot be implemented properly and thoroughly.

Cianjur Regency, as part of the territory of the Republic of Indonesia located in Central Java Province, is divided into 32 Districts, 342 Villages, and 6 Subdistricts. Based on data obtained from the Department of Population and Civil Registration in 2014, the populations of Cianjur Regency were $2,280,766$ people. The ownership of Family Cards (KK) only reached $49 \%$ of the mandatory number of KK ownership or only 431,519 people who had

\footnotetext{
* Corresponding Author

Phone : +62 8127112066

Email : hardiyansyah@binadarma.ac.id
} 
registered their KKs (from the mandatory number of KK's total of 873,939 people). The Family Card is a Family Identity Card which contains data on the arrangement, relationships, and a number of family members. Family Card must be owned by every family. This card contains complete data about the identity of the Family Head and his family members. To create a family card, a family must complete the following requirements: Letter of the Board of the Neighborhood (RT) and/or Rukun Warga (RW); Old Family Card; Marriage Certificate or Divorce Certificate for making a KK due to marriage/divorce; Birth Certificate; Letter of Appointment of Children; Certificate of Registration for Permanent Residents for Foreigners; Certificate of Newcomer Reporting (SKPPB) for immigrants from outside their territory; Certificate of Relocation for residents who moved between kelurahan within their territory ("Kartu keluarga - Wikipedia bahasa Indonesia, ensiklopedia bebas," n.d.).

While the ownership of ID card (KTP) as another important document of citizenship is owned by every citizen of Indonesia in the age of 17 years old and above, it only reached the level of $71 \%$ of the mandatory number of KTP ownership. Furthermore, KTP as citizens' identity cards should refer to the data recorded in the KK. However, in reality, the phenomena occurring shows that there are still many cases in the form of irregularities regarding KTP ownerships, such as the presence of people who have multiple KTPs, false data in KTPs or KTPs that are not based on the family cards. Although the government has declared that the entire population of Indonesia already has a single Population Identity Number that can be used for a lifetime, but until now, this target is very difficult to be achieved because the facilities and infrastructures to implement the mandate of Law of the Republic of Indonesia Number 23 Year 2006 have not been evenly distributed throughout territory of Indonesia, including in Cianjur Regency.

Based on the facts and total data of KK and KTP owners as described previously, the service process to register KK and KTP has not been well managed, correct and effective. It can be caused by internal factors, among others: technological facilities and infrastructures are still inadequate, and apparatus as implementers who provide services are not professional. While the external factors for example low awareness of the people to have an identity, the home locations are far from the central administration services, especially in the area of South Cianjur, and requirements process of administration has a different level of difficulties. Some people who have difficulty in registering administration documents for KKs and KTPs declared that: The process of registering KKs and KTPs is convoluted and technically it is a long administrative requirement process. In addition, lack of information and socialization from the government apparatus regarding the correct procedures for registering their KKs and KTPs.

Despite the provision of fees related to population administration, there are still various service tariffs for each person without detail information about the costs used. Service discrimination still exists. It can be seen in providing service process when sometimes there are long waiting for customers to register, but they are not served yet while there are new coming customers who are directly served. Furthermore, the behavior of the apparatus providing unprofessional services may lead to unexpected errors in the process of making the KKs and KTPs.

The length of time required for the process of making KKs and KTPs is still not in accordance with the rules that have been set. Population identity and civil registration services as one of the basic services that must be implemented by the local government are very important for the community/ population because population and civil records touch all layers of society/population regardless of age, educational status, occupation or another social status. However, the above phenomena provide signal indicators as follows: 1) the presence of gaps and ineffectiveness of services performed by the administrative apparatus, 2) the limited number of competent apparatus in population administration services in Cianjur Regency, and 3) need improving self-development apparatus in accordance with more professional work, such as providing excellent service, fast and accurate to the community related to community expectations.

Several studies on the development of apparatus resources and public services had been done, such as Järvalt (2012); Paranoan (2013); Brinkerhoff \& Brinkerhoff (2015); and Indrayana, Hakim, Tjahjanulin \& Saleh (2015). In general, the results of their research indicate that the development of apparatus resources affects the quality and effectiveness of public services. Human resource development usually managed by Training and Development Department is an important organizational activity to do. The importance of human resource development activities within an organization is to maintain and improve the competence of employees in order to achieve organizational effectiveness (Yuniarsih \& Suwatno, 2008 , pp. 1-3). Pynes (2013, p. 3) points out that ...Organizations must implement training and development activities to ensure that their staffs have the requisite knowledge, skills, abilities, and other characteristics (KSAOCs) to confront these new challenges. Training can be targeted to help employees learn new job-specific skills, improve their performance, or change their attitudes. 
Followed by Laird (2003, p. 6) stated that "Training and development exist to promote individual and organizational excellence by providing opportunities to develop workplace skills".

According to Armstrong (2006, p. 332), "human resources development (HRD) is concerned with the provision of learning, development and training opportunities in order to improve individual, team and organizational performance. HRD is essentially a business-led approach to developing people within a strategic framework ". Developing human resources, in this case, the apparatus, who are effective and qualified will be the intellectual capital of the organization, can be done through the creation of a learning process (learning). Armstrong \& Baron (2005, p. 535) in the Chartered Institute of Personnel and Development (CIPD) defines the elements of the human resource development process as follows: (a) Learning - as 'a relatively permanent change in behaviour that occurs as a result of practice or experience; (b) Education - the development of the knowledge, values and understanding required in all aspects of life rather than the knowledge and skills relating to particular areas of activity; (c) Development - the growth or realization of a person's ability and potential through the provision of learning and educational experiences; and (d) Training - the planned and systematic modification of behaviour through learning events, programmes and instruction, which enable individuals to achieve the levels of knowledge, skill and competence needed to carry out their work effectively.

According to Osborne \& Gaebler (1992, pp. 203-205), the ability of the apparatus to perform services to meet social needs is an achievement for the apparatus, as well as for career coaching personnel. While Tjokroamidjojo (2001, p. 92) argues that the service is provided in an orderly, quick and direct manner to the people who need a momentary service, especially time-consuming services, to be based on transparent and widely known policies by the community to improve the quality of public services.

The goals to be sought from the development of apparatus resources in this discussion are the effectiveness of services to the community. In this study, a public service is called effective when the apparatus is able to meet the needs of society quickly and accurately in accordance with the needs of society. Related to this, Stewart (1994, p. 12) argues that the development of human resources (apparatus) as an independent variable, can realize the effectiveness of services to the community as a dependent variable, as well as employees, offered other benefits an opportunity to improve skills so that established self-maturity of work to satisfy their egoistic needs.
The service is considered as serviceability when it is including speed, competence, comfort, reparability, satisfactory in complaints handling provided in a timely manner (Tjiptono, 2008, p. 27). Related to serviceability, Fitzsimmons \& Fitzsimmons (1994, p. 190) state that basically, there are four dimensions of service: Reliability (right and true as promised), Responsiveness (awareness or willingness to help consumers), Assurance (politeness and respect to others) and Tangibles (supported by other physical facilities).

The success of services provided to the community depends on the ability, dedication, and seriousness of the personnel to do so services. One of the services performed by the apparatus is the service of population administration, for example the services of registering KKs and KTPs. Population administration according to Haryanto (2004, p. 7) is defined as a series of activities for structuring and publishing the administration and provision of data for people through the registration, in this case through publishing identity cards and population administration such as KKs, KTP, marriage certificate, deed or other population administration such as: a) civil registration and b) the management of population information and the utilization of the results in service to people. Further, Haryanto said that the registration of the population is a process of population registration which includes data collection and recording or reporting of population issues for publishing people identity administration or identity certificate issued by the Regional Government.

\section{METHOD}

This research uses survey research method as one kind of scientific research, which is by collecting information and data from respondents by using questionnaires from samples representing the entire population which allows generalization making for the population. According to Effendi \& Tukiran (2012, p. 4): Survey research can be used for the purpose of (1) exploratory, (2) descriptive, (3) explanatory or confirmatory, i.e. to explain causal relationships and hypothesis testing, 4) evaluation, (5) predicting or predicting future events, (6) operational research, and (7) development of social indicators. Population in this research is sub-district public servant related to population administration service in Cianjur Regency and public service at Population and Civil Registry Office of Cianjur Regency as many as 433 and taken samples as much as 187.The sampling technique used in this study is "proportional stratified random sampling", i.e. the determination of samples from relatively large populations into various strata whose number of population members of each stratum are not the 
same. The sample size required in this study is based on the analytical techniques used to test the hypothesis. The analytical technique to be used is Structural Equation Modeling. Based on the Structural Equation Model, the minimum required sample size is generally 5 to 10 free parameters to be estimated or at least 200 sample sizes (Hoe, 2008).

Data collection techniques used in this study through observation, documentation, and distribution of questionnaires that have been prepared to be filled by respondents. The questionnaires were distributed directly to the public service while conducting short interviews with several public servants. The questionnaire in this study was closed or, in other words, the questionnaire contained a number of questions or statements with a number of choices that had been determined by the researcher (Black \& Champion, 1992, p. 328). The structure of the question or statement in the questionnaire is based on the Likert Scale, which is a measurement scale that serves to distinguish a subject based on different degrees of ordinal characteristics possessed by the object in question (Black \& Champion, 1992, p. 164), with five alternative answers prepared in sequentially based on the relative position ranking from the higher to the lower position of each question posed by the researcher.

\section{A. Data Processing}

By measuring the variables using ordinal scales, the respondent reveals a reaction appropriate to his or her own opinion, i.e., from very high to very low levels; and the level strongly agrees up to strongly disagree. Each respondent's answer is given a score. The highest positive response was given a score of five and the lowest negative response was scored one. Questionnaire as a tool used in this research will be asked to the respondents, including apparatus to the Office of Population and Civil Registry and apparatus of several districts, to measure the development of human resources (apparatus) and effectiveness of population administration services. Before the data were analyzed, the questionnaires were processed as follows; Tabulated respondents' answer to all questions in the questionnaire. For all questions, respondents' answer was scored with ordinal scale Likert.

\section{B. Data Analysis and Hypothesis Testing}

The steps taken in conducting quantitative analysis are as follows: Each indicator by the respondent is classified into five alternative answers using an ordinal scale that describes the answer ratings. The answer of each indicator is scored between 1 and 5. To describe the respondent's answer, a descriptive statistic such as frequency distribution is displayed in the table or graphic form using Excel software. To answer the description of each variable/sub variable/dimension of this study used very high category criteria, high, high enough, low and very low. The researchers also calculated the total score with the formulation:

$$
\text { Total Score }=\sum_{i=1}^{5} f i x X_{i}
$$

By: $f i$ is the frequency of respondents who choose the category $I$; and $X i$ is the category weight of the $i$-th answer $(X i=1,2,3,4,5)$.

Furthermore, the score of this answer is transformed into percentage units so that standard categorization can be created. The transformation to percentage form is formulated as follows:

$$
\text { Total Score }(\%)=\frac{\text { Total Score }}{(5 \times n \times k)}
$$

By: 5 (five) is the maximum score of the answer choice category in the questionnaire; $n$ are many respondents; $k$ is a lot of items;

For the standard category of Total Scores (\%) is made as follows:

$$
\begin{aligned}
& \text { Minimum Score }(\%)=\frac{1}{5} \times 100=20 \% \\
& \text { Maximum Score }(\%)=\frac{5}{5} \times 100=100 \% \\
& \text { Range }(\%)=100 \%-20 \%=80 \% \\
& \text { Interval }(\%)=\frac{80 \%}{5}=16 \%
\end{aligned}
$$

So, obtained the following categorization:

Table 1.

Categorization Score of Respondents' Answers

\begin{tabular}{ccc} 
No. & Total Score Interval (\%) & Rating Category \\
\hline 1 & $20-35.99$ & Very Low \\
\hline 2 & $36-51.99$ & Low \\
\hline 3 & $52-67.99$ & High Enough \\
\hline 4 & $68-83.99$ & High \\
\hline 5 & $84-100$ & Very High \\
\hline
\end{tabular}




\section{Inferencing Analysis}

In the next stage, data analysis is done inference in accordance with the purpose of research to explain the influence/relationship between research variables in this study, namely, the variable of human resource development (apparatus) and the effectiveness variable of population administration service. Therefore, the analysis in this study is studied through the relationship structure of a series of equations using the Structural Equation Modeling (SEM) analysis tool. SEM is one of the analytical tools that have a comprehensive method for quantification and testing of substantive theories as well as analytical tools that can test the model of structural equations that explicitly take into account measurement errors in latent variables or variables that are not directly observed. SEM analysis is an analytical tool devoted to the development of models that have strong theoretical justification (Ferdinand, 2002, pp. 34-35). This technique is used to test a new theory as well as a theory that has been developed where for the proof required an empirical test. Based on the description above, here are some reasons underlying the selection or use of SEM analysis techniques by researchers: SEM can be used to confirm the theory: whether the theory used in this study in accordance with empirical data or not; By using SEM, the measurement error can be separated from the measurement results so that the results of the analysis will be more valid and reliable than other analytical techniques; By using SEM can be obtained information on which dimensions most play a role in explaining the latent variables (variables that cannot be measured directly so must use indicators), so that this information can be used as a basis in the development of human resource development variables for the achievement of effectiveness service administration.

\section{RESULTS AND DISCUSSION}

Respondents' responses to all items of questions contained in the dimensions of learning, education, development, and training are presented in Table 2.

The calculation results show that respondent opinion on the importance of all $f$ of human resource development (apparatus) contribute $67.5 \%$ or the "moderate" based on the assessment category. Table 2 shows general description that human resource development is very important and should be well implemented. Furthermore, compared to other dimensions, respondents considered that the educational and learning dimensions were running well, according to the high score of both dimensions. While the training dimension has the lowest score compared to other dimensions, although still included in the category "moderate" based on the assessment category. This can be interpreted that the training dimension has contributed well and positively to the service of population administration in Cianjur Regency.

Respondents' responses to human resource development in dimensions of learning, education, development, and training of each work unit generally provide a positive assessment, with a cumulative score of $67.4 \%$ in the "moderate" category. This indicates that according to respondents, the development of human resources (apparatus) developed by the dimension of learning, education, development and training within the Department of Population and Civil Records as well as in eighteen districts in Cianjur Regency has been

Table 2.

Respondent's Opinion on the Importance of Apparatus Resource Development, 2005

\begin{tabular}{|c|c|c|c|c|c|c|c|c|c|c|c|c|}
\hline \multirow{3}{*}{ Dimension } & \multicolumn{10}{|c|}{ Alternative Answers } & \multirow{2}{*}{\multicolumn{2}{|c|}{ Score }} \\
\hline & \multicolumn{2}{|c|}{ Strongly Agree } & \multicolumn{2}{|c|}{ Agree } & \multicolumn{2}{|c|}{ Doubtful } & \multicolumn{2}{|c|}{ Disagree } & \multicolumn{2}{|c|}{$\begin{array}{l}\text { Strongly } \\
\text { Disagree }\end{array}$} & & \\
\hline & $\mathbf{F}$ & (\%) & $\mathbf{F}$ & (\%) & $\mathbf{F}$ & (\%) & $\mathbf{F}$ & (\%) & $\mathbf{F}$ & (\%) & Total & (\%) \\
\hline Learning (X1) & 171 & 15.2 & 413 & 36.8 & 327 & 29.1 & 210 & 18.7 & 1 & 0.1 & 3909 & 69.7 \\
\hline Education (X2) & 142 & 15.2 & 405 & 43.3 & 193 & 20.6 & 193 & 20.6 & 2 & 0.2 & 3297 & 70.5 \\
\hline Development (X3) & 111 & 9.9 & 425 & 37.9 & 275 & 24.5 & 306 & 27.3 & 5 & 0.4 & 3697 & 65.9 \\
\hline Training (X4) & 73 & 6.5 & 350 & 31.2 & 428 & 38.1 & 257 & 22.9 & 14 & 1.2 & 3577 & 63.8 \\
\hline Total & 497 & 11.7 & 1593 & 37.3 & 1223 & 28.1 & 966 & 22.4 & 22 & 0.5 & 14480 & 67.5 \\
\hline
\end{tabular}

Source: Research Result, 2015

The Influence of Apparatus Resource Development on the Effectivity of Population Administration Service 
Table 3.

Respondents' Opinion on the Effectiveness of Population Administration Services by Sub-Districts in Cianjur Regency, 2015

\begin{tabular}{|c|c|c|c|c|c|c|c|c|c|c|c|c|c|c|}
\hline \multirow{3}{*}{ Sub-districts } & \multicolumn{12}{|c|}{ Dimension } & \multirow{2}{*}{\multicolumn{2}{|c|}{$\begin{array}{c}\text { Service } \\
\text { Effectiveness }\end{array}$}} \\
\hline & \multicolumn{2}{|c|}{ Y1 } & \multicolumn{2}{|c|}{ Y2 } & \multicolumn{2}{|c|}{ Y3 } & \multicolumn{2}{|c|}{ Y4 } & \multicolumn{2}{|c|}{ Y5 } & \multicolumn{2}{|c|}{ Y6 } & & \\
\hline & Total & (\%) & Total & (\%) & Total & (\%) & Total & (\%) & Total & (\%) & Total & (\%) & Total & (\%) \\
\hline Bojongpicung & 146 & 73.0 & 142 & 71.0 & 171 & 68.4 & 137 & 68.5 & 172 & 68.8 & 768 & 69.9 & 1536 & 69.9 \\
\hline Campaka & 131 & 65.5 & 135 & 67.5 & 167 & 66.8 & 125 & 62.5 & 156 & 62.4 & 162 & 64.8 & 876 & 64.9 \\
\hline Cianjur & 138 & 69.0 & 120 & 60.0 & 143 & 57.2 & 128 & 64.0 & 169 & 67.6 & 158 & 63.2 & 856 & 63.5 \\
\hline Cibeber & 128 & 64.0 & 133 & 66.5 & 156 & 62.4 & 149 & 74.5 & 160 & 64.0 & 161 & 64.4 & 887 & 66.0 \\
\hline Cikalong Kulon & 138 & 69.0 & 147 & 73.5 & 171 & 68.4 & 149 & 74.5 & 183 & 73.2 & 165 & 66.0 & 953 & 70.8 \\
\hline Cilaku & 137 & 68.5 & 141 & 70.5 & 171 & 68.4 & 144 & 72.0 & 169 & 67.6 & 175 & 70.0 & 937 & 69.5 \\
\hline Cipanas & 160 & 80.0 & 157 & 78.5 & 183 & 73.2 & 155 & 77.5 & 186 & 74.4 & 222 & 88.8 & 1063 & 78.7 \\
\hline Ciranjang & 134 & 67.0 & 133 & 66.5 & 165 & 66.0 & 148 & 74.0 & 188 & 75.2 & 200 & 80.0 & 968 & 71.5 \\
\hline Cugenang & 145 & 72.5 & 156 & 78.0 & 183 & 73.2 & 143 & 71.5 & 168 & 67.2 & 178 & 71.2 & 973 & 72.3 \\
\hline Disdukapil & 143 & 71.5 & 144 & 72.0 & 156 & 62.4 & 132 & 66.0 & 202 & 80.8 & 166 & 66.4 & 943 & 69.9 \\
\hline Gekbrong & 128 & 64.0 & 133 & 66.5 & 165 & 66.0 & 143 & 71.5 & 183 & 73.2 & 184 & 73.6 & 936 & 69.1 \\
\hline Haurwangi & 133 & 66.5 & 149 & 74.5 & 167 & 66.8 & 139 & 69.5 & 173 & 69.2 & 171 & 68.4 & 932 & 69.2 \\
\hline Karang Tengah & 139 & 69.5 & 142 & 71.0 & 166 & 66.4 & 131 & 65.5 & 157 & 62.8 & 161 & 64.4 & 896 & 66.6 \\
\hline Mande & 127 & 63.5 & 143 & 71.5 & 148 & 59.2 & 130 & 65.0 & 179 & 71.6 & 184 & 73.6 & 911 & 67.4 \\
\hline Pacet & 133 & 66.5 & 127 & 63.5 & 177 & 70.8 & 142 & 71.0 & 174 & 69.6 & 172 & 68.8 & 925 & 68.4 \\
\hline Sukaluyu & 125 & 69.4 & 124 & 68.9 & 141 & 62.7 & 111 & 61.7 & 153 & 68.0 & 147 & 65.3 & 801 & 66.0 \\
\hline Sukanagara & 114 & 63.3 & 108 & 60.0 & 130 & 57.8 & 119 & 66.1 & 191 & 84.9 & 169 & 75.1 & 831 & 67.9 \\
\hline Sukaresmi & 128 & 71.1 & 128 & 71.1 & 146 & 64.9 & 125 & 69.4 & 164 & 72.9 & 175 & 77.8 & 866 & 71.2 \\
\hline Warung Kondang & 118 & 59.0 & 121 & 60.5 & 150 & 60.0 & 112 & 56.0 & 150 & 60.0 & 157 & 62.8 & 808 & 59.7 \\
\hline Total & 2545 & 68.0 & 2583 & 69.0 & 3056 & 65.3 & 2562 & 68.5 & 3224 & 69.4 & 3225 & 69.0 & 17215 & 68.2 \\
\hline
\end{tabular}

Source: Research Result, 2015

running well. Furthermore, by comparing the score of all work units, it can be seen that the respondents working in Sukanagara sub-district gave the lowest opinion $58.7 \%$. This means that the apparatus in Sukanagara sub-district has not optimized the utilization of human resource development in the work environment. This can be seen from respondents toward the statements written in the variable of human resource development (apparatus).

Furthermore, based on the results of interviews with the Head of Department of Population and some Head of districts related to the development of human resources (apparatus) obtained information that basically the local government of Cianjur Regency has tried to develop human resources (apparatus) in realizing effective services in the population administration. The Regional Head has instructed the Head of Population Department and Head of Civil Registry to conduct training for the subdistrict apparatus to learn the population administration which refers to the Law of the Republic of Indonesia Number 23 of 2006.

To find out more about respondents' opinions from each work unit (sub-districts) on the variable of the effectiveness of population administration 
Table 4.

Test the Suitability of Statisticals Models

\begin{tabular}{|c|c|c|c|c|}
\hline No. & Statistics & Value & Criteria & information \\
\hline 1 & Chi-square & $\begin{array}{c}48.03 \\
(p=0.056) d f=34\end{array}$ & $p>0.05$ & Fit \\
\hline 2 & Chi-square/df & 1.41 & $<3$ & Fit \\
\hline 3 & RMSEA & 0.048 & $<0.08$ & Fit \\
\hline 4 & Norm Fit Index (NFI) & 0.94 & $\begin{array}{c}0.8 \leq 0.9: \text { Marginal Fit } \\
0.9-1.0: \text { Fit }\end{array}$ & Fit \\
\hline 5 & Comparative Fit Index (CFI) & 0.96 & $\begin{array}{c}0.8 \leq 0.9: \text { Marginal Fit } \\
0.9 \text { - 1.0: Fit }\end{array}$ & Fit \\
\hline 6 & Incremental Fit Index (IFI) & 0.96 & $\begin{array}{c}0.8 \leq 0.9: \text { Marginal Fit } \\
0.9 \text { - 1.0: Fit }\end{array}$ & Fit \\
\hline 7 & $\begin{array}{l}\text { Standardized Root Mean Square } \\
\text { (SRMS) }\end{array}$ & 0.070 & $\begin{array}{c}0.0-0.05: \text { Fit } \\
0.5 \text { - 1.00: Marginal Fit }\end{array}$ & Marginal Fit \\
\hline 8 & Goodness of Fit Index (GFI) & 0.900 & $\begin{array}{c}0.8 \leq 0.9: \text { Marginal Fit } \\
0.9-1.0: \text { Fit }\end{array}$ & Fit \\
\hline
\end{tabular}

Source: Research Result, 2015

services, the summary is presented in following Table 3.

Based on the data in Table 2 that each subdistrict generally gives a positive assessment of the variable effectiveness of population administration services with a cumulative score of $68,2 \%$ is in "moderate" category. This category shows that the effectiveness of population administration services in Cianjur Regency which covers six dimensions has been running quite well. By analyzing at the per-working unit score seen that respondents working in the District Cipanas provide the highest response is $78.7 \%$, it means that the apparatus agrees that the statements written in the variable of the effectiveness of population administration services. While the lowest response given by District Warungkondang of $59.7 \%$, it means that the apparatus believe Warungkondang District has not been able to provide effectively population administration services especially in providing KKs and KTPs registration services.

To analyze the suitability of the model with the data obtained, there are some statistical tests used, such as chi-square, RMSEA, NFI and other statistical test presented in Table 4.

By comparing the $P$-value with all the statistical values in Table 4 there are at least five statistical values that suggest the model matches with the data used in this research. Thus, it can be concluded that the model is compatible with the data used in this study so that the measurement model analysis can be done.
Furthermore, the result of the analysis of the measurement model on variable human resource development (apparatus) that is the path coefficient analysis and $t$ value is presented in Table 5 .

Table 5 presents the results of measurement model calculations from path coefficients (factor loading) to the significant coefficients. From the table shows that all dimensions have a path coefficient greater than 0.50 so it can be concluded that all dimensions are valid in measuring variables of human resource development (apparatus). From the results of hypothesis tests can also be seen in the description column of all dimensions expressed significantly in measuring latent variables. Furthermore, the reliability coefficient of the construct (construct reliability) has a value of 0.883 , greater than 0.700 , so it can be concluded all dimensions consistently measure latent variables of human resource development (apparatus). This value also illustrates that $88.3 \%$ of the variation in latent variables of human resource development (apparatus) can be reflected by the four dimensions of learning dimensions (X1), Education (X2), Development (X3), and Training (X4). Furthermore, the value of the extracted variance coefficient, is 0.832 , indicates that $83.2 \%$ of the diversity of these four dimensions can be explained by the latent variable of human resource development (apparatus). From these four dimensions, the most capable dimension to measure the latent variable of human resource development (apparatus) is learning dimension (X1) and development (X3) 
Table 5.

Variable Measurement Model Analysis Human Resource Development (Apparatus)

\begin{tabular}{lcccccc}
\multicolumn{1}{c}{ Dimension } & Factor Loading & $\mathbf{R}^{2}$ & Error Variance & $t$ Count & $t$ Table & Information \\
Learning (X1) & 0.870 & 0.757 & 0.243 & 9.310 & 1.969 & Significant \\
\hline Education (X2) & 0.780 & 0.608 & 0.392 & 8.430 & 1.969 & Significant \\
\hline Development (X3) & 0.820 & 0.672 & 0.328 & 8.970 & 1.969 & Significant \\
\hline Training (X4) & 0.760 & 0.578 & 0.422 & 8.660 & 1.969 & Significant \\
\hline Construct Reliability & 0.883 & & & & & \\
\hline Extracted Variance & 0.832 & & & & & \\
\hline
\end{tabular}

Source: Research Result, 2015

with path coefficient for each is 0.87 and 0.82 . While the lowest dimension path coefficient is the training dimension with the path coefficient of 0.76 . These results indicate that the development of human resources (apparatus) will be evident from the learning dimension (X1) and development (X3) and less clearly illustrated from the training dimension (X3).

After that, the result of the analysis of the measurement model of the variable of the effectiveness of the population administration services, the path coefficient, and the $t$ value are presented in Table 6.

Table 6 presents the results of measurement model calculations from the path coefficient (loading factor) to the coefficients significance. From the table shows that all dimensions have path coefficient greater than 0.50 so it can be concluded that all dimensions are valid in measuring latent variable of the effectiveness of population administration services. From the results of hypothesis testing can also be seen in the description column of all dimensions expressed significantly in measuring latent variables. Furthermore, the reliability coefficient of the construct (construct reliability) has a value of 0.963 , greater than 0.700 , so it can be said that all dimensions consistently measure the latent variable of the effectiveness of population administration services. This value also illustrates that $96.3 \%$ of the variability of latent variables in the effectiveness of population administration services can be reflected by the six dimensions, namely the dimensions of clarity and certainty (Y1), accuracy and speed (Y2), ease and simplicity (Y3),

Table 6.

Analysis of the Variable Measurement Model of Effectiveness of Population Administration Services

\begin{tabular}{llccccc}
\multicolumn{1}{c}{ Dimension } & $\begin{array}{c}\text { Factor } \\
\text { Loading }\end{array}$ & $\mathbf{R}^{\mathbf{2}}$ & $\begin{array}{c}\text { Error } \\
\text { Variance }\end{array}$ & $t$ count & $t$ table & Information \\
Clarity and Certainty (Y1) & 0.890 & 0.792 & 0.208 & 17.340 & 1.969 & Significant \\
\hline Accuracy and Speed (Y2) & 0.920 & 0.846 & 0.154 & 18.160 & 1.969 & Significant \\
\hline Ease and Simplicity (Y3) & 0.930 & 0.865 & 0.135 & 15.280 & 1.969 & Significant \\
\hline Wisdom and Empathy of Ministry (Y4) & 0.930 & 0.865 & 0.135 & 16.180 & 1.969 & Significant \\
\hline Openness (Y5) & 0.920 & 0.846 & 0.154 & 14.220 & 1.969 & Significant \\
\hline Public Awareness as a Citizen (Y6) & 0.820 & 0.672 & 0.328 & 9.430 & 1.969 & Significant \\
\hline Construct Reliability & 0.963 & & & & & \\
\hline Extracted Variance & 0.955 & & & & & \\
\hline
\end{tabular}

Source: Research Result, 2015 


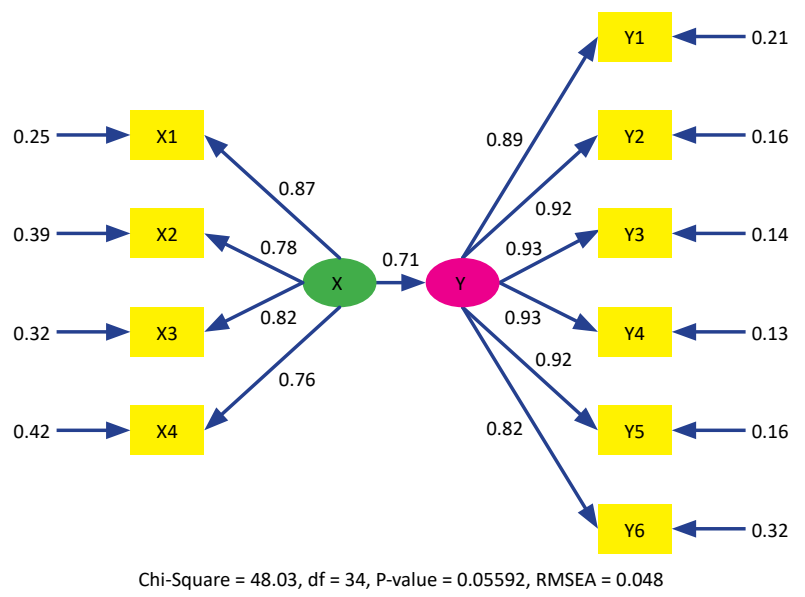

Figure 1. Flowchart of the Influence of Human Resource Development (Apparatus) to the Effectiveness of Service Administration Services (Standardized Coefficient)

wisdom and empathy of service (Y4), openness (Y5) and public awareness as citizen (Y6) Then, the value of extracted variance coefficient, which is 0.955 , shows that $95.5 \%$ of the diversity of this dimension can be explained by the latent variable of the effectiveness of population administration services. It shows that all the dimensions have a large loading factor coefficient so that these six dimensions are able to reflect the latent variable of the effectiveness of population administration services, in particular, the dimension of ease and simplicity and the dimension of wisdom and empathy service have the highest loading factor coefficient compared to other dimensions.

After analyzing the measurement model, it can be concluded that all dimensions are valid and reliable in measuring the latent variables; following presents structural model analysis. The structural model analysis is the influence analysis of one latent variable toward other latent variables. In this study structural model analysis is the influence analysis of human resource development (apparatus) on the effectiveness of population administration services.
Structural analysis model includes testing the significance of the influence of human resource development (apparatus) on the effectiveness of population administration services in Cianjur regency and how much influence of exogenous variables to endogenous variables as shown in Figure 1 and Figure 2.

Figure 1 and 2 are structural equation models in this research that reflect structural equation and measurement equation. The structural equation shows the relationship between exogenous latent variable (variable of human resource development (apparatus) with endogenous variable (effectiveness variable of population administration service). While the measurement equation shows the relationship among dimensions in exogenous latent variables and dimensions in endogenous latent variables.

From the calculation, the path coefficient of human resource development (apparatus) variable to the effectiveness of population administration service is 0.71 with a $t$ value of 8.51 with variance error of 0.50 . The path coefficient of 0.71 shows

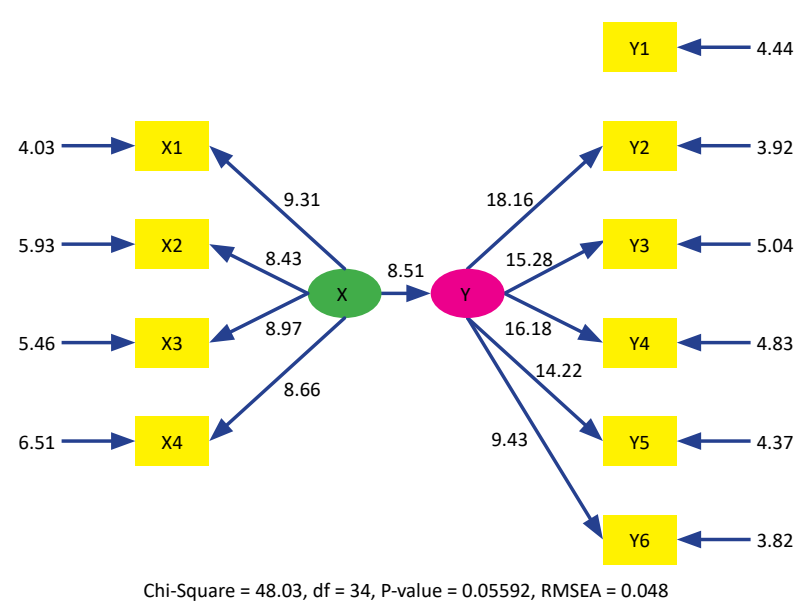

Figure 2. Flowchart of the Influence of Human Resource Development (Apparatus) on the Effectiveness of Population Administration Services ( $t$ student)

The Influence of Apparatus Resource Development on the Effectivity of Population Administration Service 
that the influence of human resource development (apparatus) to the effectiveness of population administration services of 0.71 , one of standard deviation. By squaring the path coefficient is obtained a coefficient of determination with the value of 0.5041 . This value explains that $50,41 \%$ diversity of effectiveness of administration service variable can be explained by a variable of human resource development (apparatus). While the rest known as the variance error of 0.4959 explains that $49.59 \%$ of the diversity of the effectiveness of population administration services explained by other variables not included in this study.

The result of $t$ value of 8.51 with the value of $t$ table on the degree of freedom 175 and the significance level of $5 \%$ is 1974 . The criterion of rejection of the null hypothesis (Ho) is rejected and the alternative hypothesis is accepted if the value of $t$ value is greater than the value of $t$ table. It shows that the value of $t$ value (8.51) is greater than $t$ table (1.974) so that it can be decided the null hypothesis is rejected and the alternative hypothesis is accepted or in other words there is a significant influence of the development of human resources (apparatus) to the effectiveness of population administration services.

Based on the explanation of $t$ value and $t$ table it can be summarized that test results of the influence of human resources development (apparatus) to the effectiveness of administrative respondents shows exogenous variables of human resources development (apparatus) Has $t$ value (8.51) larger than $t$ table (1.974), so it can be concluded that: "human resource development (apparatus) has a significant effect on the effectiveness of population administration services in Cianjur regency".

Thus, the hypothesis tested in empirical (tested hypothesis) in this study shows "rejection of the null hypothesis (H0) and accept the alternative hypothesis (H1)", namely the development of human resources (apparatus) positively and significantly influence the effectiveness of administrative services Population in Cianjur Regency. "

The magnitude scale of the influence of human resource development to the effectiveness of population administration services in Cianjur Regency based on statistical model analysis can be explained by the model: Service Effectiveness $=0.71$ PSDM + 0.39 Epsilon.

This statistical model can be interpreted that the variable of human resource development has an influence of 0.71 standard deviations to the effectiveness of population administration services in Cianjur Regency. This result implies that if there is a positive change in the variable of human resource development in one standard deviation, the effectiveness of population administration service will increase by 0.71 one standard deviation of structural model analysis obtained by the proportion of variance of effectiveness variable of population administration service which can be explained by variable of developing human resources reached $71 \%$. This value implies that human resource development has a "strong" influence (within the coefficient interval 0.60-0.799) to the effectiveness of population administration services.

The calculation results of the influence of human resource development (apparatus) to the effectiveness of the population administration service shows that the direct influence of the development of human resources (apparatus) on the effectiveness of the population administration service is 0.71 . While the influence of human resource development (apparatus) indirectly to the clarity and certainty indicator of 0.63 ; to the accuracy and speed indicator of 0.65 ; to ease and simplicity of 0.66 ; To the wisdom and empathy of 0.66 ; to openness of 0.65 ; And to the public awareness indicator as a citizen of 0.58 . The above results show that the influence of human resource development (apparatus) to the effectiveness of population administration services seen from changes in indicators of ease and simplicity and wisdom and empathy service. By looking at the indicators of ease and simplicity and also the wisdom and empathy of service, the following conclusions describe that: The ease and simplicity indicator requires a good knowledge of the apparatus, both related to the operational processes of the services provided and the ability to fulfill the requested services. Therefore, competence becomes a keyword in the improvement of these indicators.

The indicator of wisdom and empathy service requires a professional attitude as well as an understanding concept of public servants. It is related to the ability of the apparatus to communicate with the service user and also the leading spirit of the apparatus.

From the two descriptions above show the elements of human resources that must be owned by the apparatus to create service effectiveness to the public. It supports the researcher's hypothesis that the development of human resources (apparatus) has a significant effect in improving the effectiveness of services to the public.

Furthermore, the analysis shows that there is a significant influence of the development of human resources (apparatus) to the effectiveness of population administration services with influence of 0.71 standard deviation and total diversity of effectiveness of population administration services which can be explained by the development of 
human resources (apparatus) of 50, 41\%; While the remaining $49.59 \%$ can be explained by other variables not included in this research.

The relationship between human resource developmentand the effectivenessintheorganization basically has been expressed by experts, it stated by Armstrong (2006), that: The organizational process of developing people involves the integration of learning and development processes, operations and relationships. Its most powerful outcomes for the business are to do with enhanced organizational effectiveness and sustainability. For the individual, they are to do with enhanced personal competence, adaptability, and employability. It is, therefore, a critical business process for-profit or not-for-profit organization.

The above theory explains that the process of developing human resources in an organization involves learning, development, operation, and relationship as a whole. The most important result of the human resource development process for an organization is the increasing of the effectiveness and survival of the organization. The effect of human resource development on an individual is the increasing ability of the individual (competence), adaptability and work of the individual concerned. Therefore, the development of human resources is a very important process for both profit-oriented and non-profit organizations. Development of human resources to every organization large or small is needed to support the organizational goals that have been established. In the process of developing human resources in an organization can be done in various ways such as learning, education, development, and training.

Referring to the data and views of experts above, it can be argued that to improve the effectiveness of the organization should be supported by the development of people who work within the organization. Regarding the results of this research shows that $50.41 \%$ of improvement in the effectiveness of population administration services can be explained by the variables of human resource development (apparatus) through the dimensions of learning, education, development, and training.

The significant influence of the development of human resources (apparatus) to the effectiveness of population administration services in Cianjur Regency basically cannot be separated from the efforts made by the Department of Population and Civil Registry and the district administration office in Cianjur Regency to develop the potential of the apparatus in Population administration service. This effort is certainly an appropriate action because the existence of human resources in an organization is very important. Human resource is one of the first resources and especially in achieving the goals of an organization in addition to other resources. Siagian (2000, pp. 1-7) says it is true that human resources and other resources and are important and necessary, but they are only means and work infrastructure that enables an organization to carry out the tasks. It is important to realize in human beings these various resources and powers are merely "inanimate object" and transform into "living object" when mobilized and used by humans.

Furthermore, the magnitude scale of the influence of human resource development (apparatus) to the effectiveness of population administration services in Cianjur Regency as mentioned above, is basically a reflection of the accumulated results of its four dimensions. The dimension that has the lowest value of its ability to reflect the variable of human resource development (apparatus) is the training dimension (X4); while the greatest ability is the learning dimension (X1).

\section{Conclusion}

This research reveals that of the four dimensions tested and analyzed gives the following conclusions: The learning dimension has the greatest impact on the development of human resources (apparatus) due to the apparatus learning process does not require a large cost but the apparatus willingness to gain new knowledge, both from within or outside the workplace environment; The educational dimension takes place on third in influencing the development of human resources (apparatus). Apparatus who participated in this study argues that it is important to continue formal education to expand the horizons of thinking and to support their career; The development dimension is on the second largest in terms of human resource development (apparatus). The development means that how the apparatus undergoing the process of learning and education can work better and professional; The training dimension is the smallest dimension that contributes to the development of human resources. The small value of training due to the implementation of training for the apparatus of the Department of Population and Civil Registry and subdistrict apparatus is still very limited due to the limited availability of funds and facilities for training.

\section{ACKNOWLEDGEMENT}

This research was supported by LPPM Muhammadiyah University of Sukabumi, LPPM Universitas Bina Darma and Government of Cianjur Regency. We are thankful to our colleagues who have supported the research that has been provided who provided expertise that greatly assisted the this research. 


\section{REFERENCES}

Armstrong, M. (2006). A Handbook of Human Resource Management Practice (10th ed.). Kogan Page Publishers.

Armstrong, M., \& Baron, A. (2005). Managing Performance: Performance Management in Action. CIPD Publishing.

Black, J. A., \& Champion, D. J. (1992). Methods and Issues in Social Research. John Willey \& Sons.

Brinkerhoff, D. W., \& Brinkerhoff, J. M. (2015). Public Sector Management Reform in Developing Countries: Perspectives Beyond NPM Orthodoxy. Public Administration and Development2, 35(4), 222-237. http://doi. org/10.1002/pad.1739

Effendi, S., \& Tukiran (Eds.). (2012). Metode Penelitian Survei. Jakarta: Pustaka LP3ES.

Ferdinand, A. T. (2002). Structural Equation Modeling dalam Penelitian Manajemen. Semarang, Indonesia: Badan Penerbit Universitas Diponegoro.

Fitzsimmons, J. A., \& Fitzsimmons, M. J. (1994). Service Management for Competitive Advantage. McGraw-Hill.

Haryanto, R. (2004). Kebijakan dan Arah Penyelenggaraan Administrasi Kependudukan (Policy and Direction of Population Administration). Jakarta: Direktorat Jenderal Administrasi Kependudukan Departemen Dalam Negeri.

Hoe, S. L. (2008). Issues and Procedures in Adopting Structural Equation Modeling Technique. Journal of Applied Quantitative Methods, 3(1), 76-83. Retrieved from http://www.jaqm.ro/ issues/volume-3,issue-1/7_hoe.php

Indrayana, S., Hakim, A., Tjahjanulin, \& Saleh, C. (2015). Apparatus Resource Development and Its Impact on Public Services at the Government of Sidoarjo Regency East Java Province. Public Policy and Administration Research, 5(7), 1-8. Retrieved from http://
www.iiste.org/Journals/index.php/PPAR/ article/view/24020

Järvalt, J. (2012). Strategic Human Resource Management in the Public Service: Evidence from Estonia and Other Central and Eastern European Countries. Tallinn University of Technology. Retrieved from https://digi.lib.ttu. ee/i/?743\&

Kartu keluarga - Wikipedia bahasa Indonesia, ensiklopedia bebas. (n.d.). Retrieved March 27, 2018, from https://id.wikipedia.org/wiki/ Kartu_keluarga

Laird, D., Holton, E. F., \& Naquin, S. S. (2003). Approaches to Training and Development (3rd ed.). Cambridge: Perseus Publishing.

Law of the Republic of Indonesia Number 23 of 2006 concerning Population Administration, Pub. L. No. 23 (2006). Indonesia.

Osborne, D., \& Gaebler, T. (1992). Reinventing Government: How the Entrepreneurial Spirit is Transforming the Public Sector (10th ed.). Addison-Wesley Publishing Company.

Paranoan, D. B. (2013). Apparatus Resources Development Model to Improve Public Service Quality in Indonesia. Journal of Information Engineering and Applications, 3(3), 38-46. Retrieved from http://iiste.org/Journals/ index.php/JIEA/article/view/4872

Pynes, J. E. (2013). Human Resources Management for Public and Nonprofit Organizations: $A$ Strategic Approach (4th ed.). San Francisco: John Wiley \& Sons, Inc.

Siagian, S. P. (2000). Organisasi, Kepemimpinan dan Perilaku Administrasi. Jakarta: Gunung Agung.

Stewart, A. M. (1994). Empowering People. Pitman Publishing.

Tjiptono, F. (2008). Prinsip-prinsip Total Quality Service. Yogyakarta: Andi Publisher.

Tjokroamidjojo, B. (2001). Pengantar Administrasi Pembangunan. Jakarta: LP3ES.

Yuniarsih, T., \& Suwatno. (2008). Manajemen Sumber Daya Manusia. Bandung: CV. Alfabeta. 